Engineer Research and

Development Center

Engineering Site Identification for the Tactical Environment (ENSITE)

\title{
Identifying Key Factors Relevant for Base Camp Siting
}

Jeffrey C. Cegan, George W. Calfas, and Matthew E. Bates

December 2017

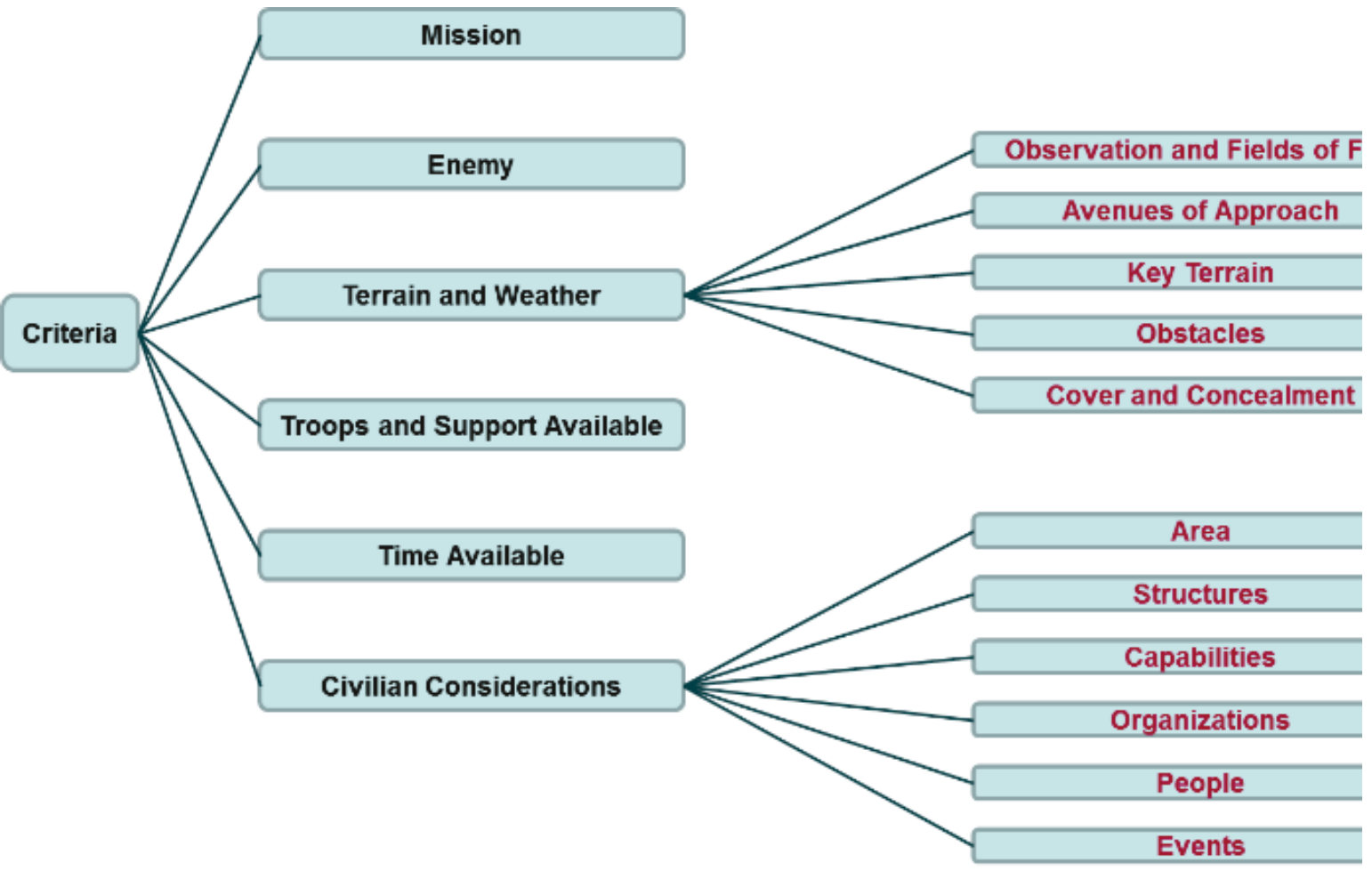


The U.S. Army Engineer Research and Development Center (ERDC) solves the nation's toughest engineering and environmental challenges. ERDC develops innovative solutions in civil and military engineering, geospatial sciences, water resources, and environmental sciences for the Army, the Department of Defense, civilian agencies, and our nation's public good. Find out more at www.erdc.U.S.ace.army.mil.

To search for other technical reports published by ERDC, visit the ERDC online library at http://acwc.sdp.sirsi.net/client/default. 


\section{Identifying Key Factors Relevant for Base Camp Siting}

Jeffrey C. Cegan and Matthew E. Bates

Environmental Laboratory

U.S. Army Engineer Research and Development Center

EL Risk and Decision Science Team

at USACE New England District Office

696 Virginia Road

Concord, MA 01742

George W. Calfas

Construction Engineering Research Laboratory

U.S. Army Engineer Research and Development Center

2902 Newmark Drive

Champaign, IL 61822

Final report

Approved for public release; distribution is unlimited.

Prepared for Assistant Secretary of the Army for Acquisition, Logistics, and Technology ASA(ALT)

103 Army Pentagon

Washington, DC 20314-1000

Under Project 455009, "Contingency Base Site Evaluations for Tactical Environment" 


\section{Abstract}

To sustain itself as the world's premier land power, the U.S. Army needs the capability to support expeditionary forces by projecting a minimal basing footprint with reduced logistical burdens. Strategically sited contingency bases (CBs) allow the Army's expeditionary forces to rapidly respond throughout a joint area of operations. To assist with this goal, the Army is funding work in the Engineer Site Identification for the Tactical Environment (ENSITE) program, which is dedicated to empowering military planners with the data and knowledge to site CB locations. The work reported here explores reasonable analytical framings for the site suitability analysis, including identification of appropriate methods, criteria, and parameters for evaluating different spatial areas for suitability as new CBs. This work utilizes the specialized capabilities and knowledge of the U.S. Army Engineer, Research, and Development Center's Risk and Decision Science Team (RADS), who worked with ENSITE colleagues and subject matter experts to identify key factors relevant for locating CBs.

DISCLAIMER: The contents of this report are not to be used for advertising, publication, or promotional purposes. Citation of trade names does not constitute an official endorsement or approval of the use of such commercial products. All product names and trademarks cited are the property of their respective owners. The findings of this report are not to be construed as an official Department of the Army position unless so designated by other authorized documents. 


\section{Contents}

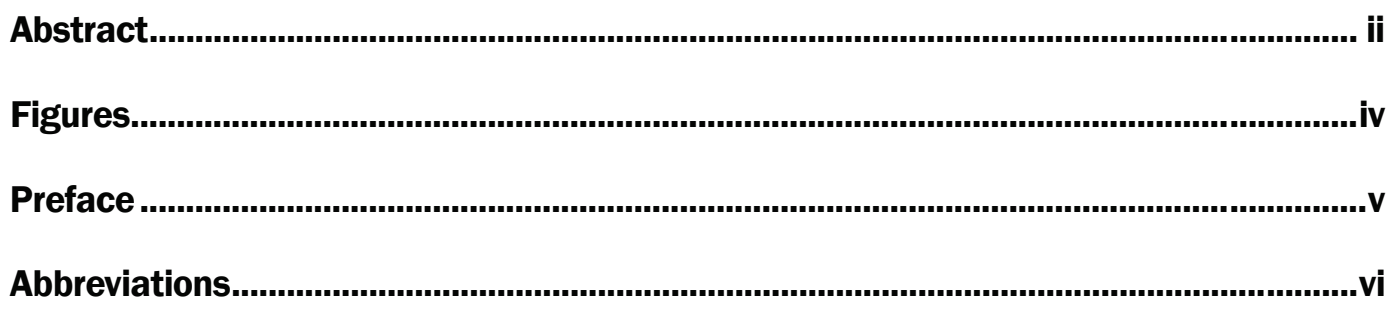

1 Introduction

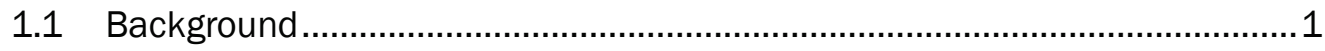

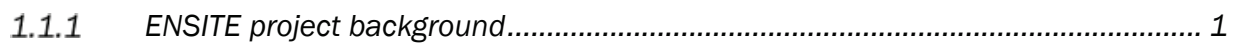

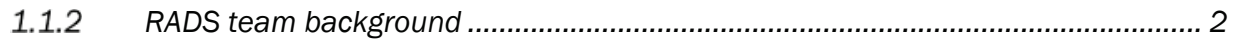

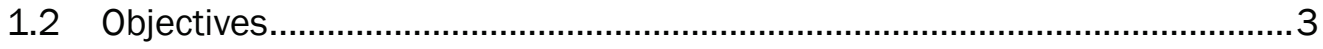

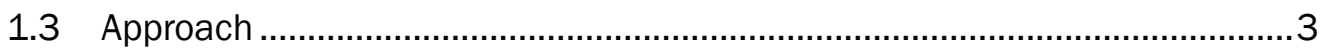

2 Methods for Developing a Decision Framework …...................................................... 4

2.1 Historical examples ............................................................................. 4

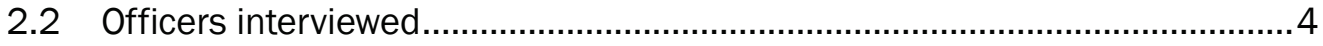

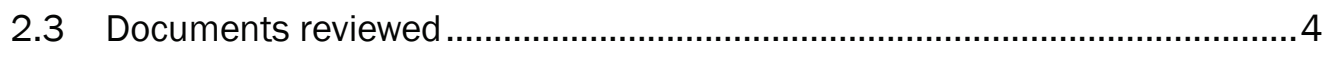

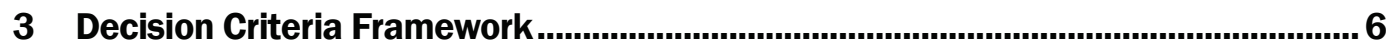

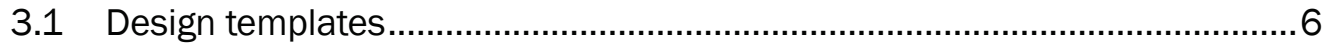

3.2 Criteria framework and definitions.......................................................... 7

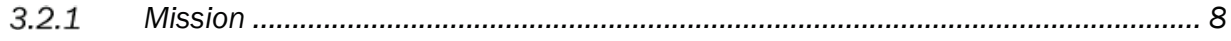

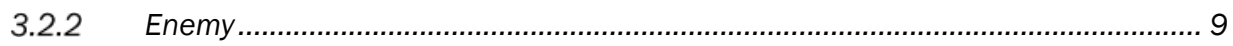

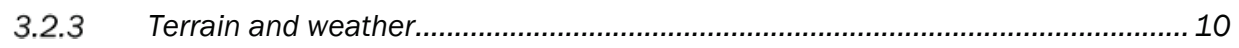

3.2.4 Troops and support available ........................................................................... 13

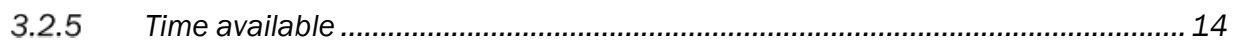

3.2.6 Civilian considerations................................................................................. 14

3.3 ENSITE scoring of criteria for site suitability .......................................... 18

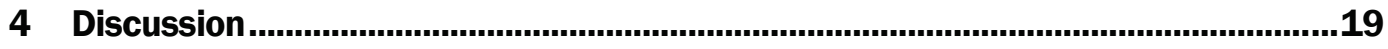

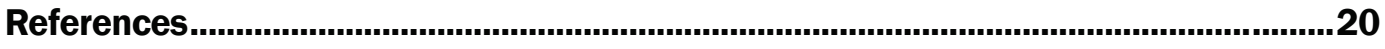

Appendix A: Past Examples ....................................................................................................21

Report Documentation Page 


\section{Figures and Tables}

\section{Figures}

Figure 1. Army-familiar categories of METT-TC, OAKOC, and ASCOPE are shown as branches and criteria within the decision tree.

Figure 2. Mission criteria highlighted within the decision tree............................................. 9

Figure 3. Enemy criteria highlighted within the decision tree.

Figure 4. Terrain and weather criteria (in green at right) are highlighted within the decision model. Note that they are subdivided from the OAKOC objectives.

Figure 5. Troops and support available criterion is highlighted by red outline....................14

Figure 6. Time-available criteria are highlighted by red outline.

Figure 7. Civilian considerations criteria are highlighted in green and connected to ASCOPE considerations shown in red.

Figure 8. Preliminary site analysis, with red as least suitable site and green as most suitable site.

\section{Tables}

Table 1. Design choice factors. Each engagement scenario will have features that relate to different design choices for the base. These features influence how the criteria in the decision framework should be prioritized. .

Table 2. Example design choice factors for an Afghan COP. 


\section{Preface}

This study was conducted for the Assistant Secretary of the Army for Acquisition, Logistics, and Technology ASA(ALT) under applied research program T45, Project 455009, "Contingency Base Site Evaluations for Tactical Environment." Mr. Kurt Kinnevan was the technical monitor for Adaptive and Resilient Installations, CEERD-CZT.

The work was performed by the Environmental Risk Assessment Branch (EPR) of the Environmental Processes and Engineering Division (EP) at the U.S. Army Engineer Research and Development Center Environmental Laboratory (ERDC-EL) in Vicksburg, MS, and by the Environmental Processes Branch (CNE) of the Installations Division (CN) at the Construction Engineering Research Laboratory, U.S. Army Engineer Research and Development Center (ERDC-CERL) in Champaign, IL.

At the time of publication, Dr. William Nelson was Chief, CEERD-EPR, and Warren Lorentz was Chief, CEERD-EP. The Deputy Director of ERDC-EL was Dr. Jack Davis, and the Director was Dr. Ilker Adiguzel. Mr. H. Garth Anderson was Chief, CEERD-CNE, and Mr. Donald K. Hicks was Acting Chief, CEERD-CN. The Interim Deputy Director of ERDC-CERL was Ms. Michelle J. Hanson, and the Interim Director was Dr. Kirankumar V. Topudurti.

The authors thank each of the Army officers who provided input in developing the framework presented in this report.

The Commander of ERDC was COL Bryan S. Green, and the Director was Dr. David W. Pittman. 


\section{Abbreviations}

\begin{tabular}{|c|c|}
\hline Abbreviation & Spell-out \\
\hline ADP & Army Doctrine Publication \\
\hline ADRP & Army Doctrine Reference Publication \\
\hline $\mathrm{AO}$ & area of operations \\
\hline $\mathrm{AOI}$ & area of interest \\
\hline ASCOPE & Area, Structures, Capabilities, Organizations, People, Events \\
\hline ATP & Army Techniques Publication \\
\hline CCR & Central Command Regulation \\
\hline CERL & Construction Engineering Research Laboratory \\
\hline $\mathrm{CB}$ & contingency basing \\
\hline CBRN & chemical, biological, radiological and nuclear \\
\hline COIN & counterinsurgency \\
\hline COP & combat outpost \\
\hline DoD & Department of Defense \\
\hline EL & Environmental Laboratory \\
\hline ENSITE & Engineer Site Identification for the Tactical Environment \\
\hline ERDC & Engineer Research and Development Center \\
\hline FOB & forward operating base \\
\hline FY & fiscal year \\
\hline GEAR & Geocentric Environment for Analysis and Reasoning \\
\hline $\mathrm{HN}$ & host nation \\
\hline LZ & landing zone \\
\hline METT-TC & $\begin{array}{l}\text { Mission, Enemy, Terrain and Weather, Troops and Support } \\
\text { Available, Time Available, Civilian Considerations }\end{array}$ \\
\hline OAKOC & $\begin{array}{l}\text { Observation and Fields of Fire, Avenues of Approach, Key Terrain, } \\
\text { Obstacles, Cover and Concealment }\end{array}$ \\
\hline $\mathrm{OP}$ & observation post \\
\hline PMESII-PT & $\begin{array}{l}\text { Political, Military, Economic, Social, Infrastructure, Information, } \\
\text { Physical Environment, and Time }\end{array}$ \\
\hline RADS & risk and decision science \\
\hline SAHARA & Spatial Analyses for Humanitarian Assistance Resource Allocation \\
\hline SOUTHCOM & Southern Command (U.S.) \\
\hline
\end{tabular}




$\begin{array}{ll}\text { TMPAST } & \text { Threat-Mapped Protection Assessment and Simulation Tool } \\ \text { TRADOC } & \text { Training and Doctrine Command (U.S. Army) } \\ \text { TSLOW } & \text { Terrain, Slope, Landing zone, Obstacles, Wind } \\ \text { USACE } & \text { U.S. Army Corps of Engineers } \\ \text { VBIED } & \text { Vehicle-borne improvised explosive device }\end{array}$


(Intentionally blank.) 


\section{Introduction}

\subsection{Background}

\subsubsection{ENSITE project background}

The Army must have an ability to rapidly plan and locate engineering sites, such as soldier base camps or other constructed facilities, for supporting maximum combat effectiveness of deployed forces. By defining missionspecific site requirements prior to force deployment and facility construction, Army commanders and planners are able to optimize siting and design decisions.

The U.S. Military has recently experienced several prominent failures in base camp siting, where omission or inadequate consideration of a full range of relevant factors led to substantial risk, damage, or loss, including loss of life. Acknowledgement is also growing of the need to ensure sufficient connectivity between engineering sites and resiliency in their supply chains. Furthermore, Army leaders recognize the inadequacy of current doctrine for conducting operations in dense urban environments and the desire to improve doctrine to consider a fuller range of relevant criteria (U.S. Army Chief of Staff 2013).

The FY16-FY18 Engineering Site Identification for the Tactical Environment (ENSITE) project seeks to address these problems by developing a comprehensive and integrated tool for assessing base camp site suitability. In FY16, the Engineer Research and Development Center-Environmental Laboratory (ERDC-EL) Risk and Decision Science (RADS) team supported the ENSITE project by developing a generalized decision support framework for evaluating potential locations for military base camps, which is presented in this report. This effort will feed into a screening-level framework of site-selection criteria and design-choice considerations to be included in future computer-aided ENSITE suitability analysis tools.

As a screening tool, ENSITE will assist with the selection of promising locations that are suitable for more detailed investigation. The tool will also guide users in becoming aware of a fuller range of factors that require consideration during site selection. Considering these factors will help to avoid the unintended consequences that sometimes follow site selection 
and facility placement. ENSITE will be especially relevant for base camps that will exist longer than temporary encampments.

\subsubsection{RADS team background}

The risk and decision science (RADS) team provides in-house research and development as well as project consultation to the U.S. Army in risk and decision science. RADS team projects often intersect data analytics, risk assessment, and decision support. The team previously supported two projects on contingency operations in Afghanistan that were designed to prioritize technology alternatives. RADS personnel also were involved in three other recent ERDC projects, namely Spatial Analysis for Humanitarian Assistance Resource Allocation (SAHARA), Geocentric Environment for Analysis and Reasoning (GEAR), and Army Hydropower Screening. These projects leveraged the team's expertise in developing analytic frameworks for the application of geospatial decision analysis to problems of site suitability.

Through the SAHARA project, the team works with the Pacific Disaster Center and U.S. Southern Command (SOUTHCOM) to identify the factors and supporting spatial data most relevant for projects involving Department of Defense (DoD) humanitarian assistance and disaster response.

Through the GEAR project (Matthew Bates - co-technical lead), the team works with software developers to create a software tool that can quickly and seamlessly ingest spatial data to facilitate interactive decision analyses like those outlined by SAHARA and ENSITE.

Through the U.S. Army Hydropower Analysis project (Matthew Bates, technical lead), the team used dam, environmental, installation, and electrical grid data to identify promising locations for new hydropower development near U.S. Army installations.

The team is also developing multiple geospatial optimization tools and algorithms for Civil Works programs and is contributing to both a U.S. Army Corps of Engineers (USACE) resilience roadmap and a set of sustainability operating principles to integrate resilience and sustainability concepts in USACE operations, including contingency operations. 


\subsection{Objectives}

During fiscal year (FY)16 and FY17, the RADS team worked with ENSITE colleagues and subject matter experts to identify key factors relevant for locating engineering sites. The team's objectives were to provide the ENSITE team with the following: (1) summary of U.S. Army personnel's knowledge in base camp siting, (2) analysis of current U.S. Army policy and publications for base camp siting, (3) development of a preliminary set of spatial criteria (i.e., factors that influence CB siting), and (4) development of a preliminary framework set of design choices (i.e., factors that will influence how base siting criteria are interpreted under different scenarios).

\subsection{Approach}

The authors reviewed literature and media sources that highlighted historical examples where base camps failed. They then interviewed over a dozen current and former Army officers with active-duty CB siting experience to better understand the Army's historical considerations for base camp selection in the field. They also reviewed relevant military protocols for additional background, context, and evidence or verification of historical base camp selection methodologies.

After initial review, a list of the most common criteria was developed from the conversations and information in publicly available documents. Criteria were sorted into a hierarchical framework based on commonly used military mission-related acronyms including METT-TC (mission, enemy, terrain and weather, troops and support available, time available, civilian considerations), ASCOPE (area, structures, capabilities, organizations, people, events), and OAKOC (observations and fields of fire, avenues of approach, key terrain, obstacles, cover and concealment). The function of the decision tree developed for this work is to evaluate total site suitability across a holistic set of tactical considerations. 


\section{Methods for Developing a Decision Framework}

\subsection{Historical examples}

There are important lessons to learn from failed base camps, particularly when their failure is related to site-specific conditions. The historical examples that we examined include five base camps in Afghanistan, one base camp in Iraq, one base camp in South Korea, one base camp in Kosovo, and one air base in Uzbekistan. Appendix A gives a synopsis of each camp, and then highlights specific criteria in which inadequate consideration may have led to the unanticipated and negative outcomes. These examples and their details come primarily from talking with personnel who had direct or indirect knowledge of these events.

\subsection{Officers interviewed}

The RADS team consulted with fourteen U.S. Army officers who had firsthand experience living on and/or constructing base camps. These conversations (informal interviews) provided insight and understanding of current base camp operations and the criteria relevant to base camp siting. The conversations were conducted orally, in-person, or over the phone. The interviewees included one Colonel (COL Howard Malone), one Lieutenant Colonel (LTC Edward Lefler), and twelve Captains (CAPTs Dan Sullivan, Zach Griffiths, Adam Harmon, James Shafer, Sam Perlik, Jon Cheatwood, Jonathan Andrade, Patrick Kuiper, Dan Brady, Phil Ambrose, Bennie Weaver, and Daniel Konakis).

\subsection{Documents reviewed}

The RADS team reviewed a variety of military documents to gain an understanding of base camps operations and doctrine relevant to their construction and safety. The following documents proved most helpful for providing additional background and context, and many of these are cited within the text of this report (see reference list for full publication details):

- USACE Overseas Contingency Operations Playbook, No 16-01

- Base Camp Facilities Standards for Contingency Operations (the Red Book) 
- U.S. Army Training and Doctrine Command (TRADOC) Pamphlet (2009)

- Gingras (2013) "The Challenge of Modern Contingency Base Management during Sustained Land Operations"

- Hyperion Threat-Mapped Protection Assessment and Simulation Tool (TMPAST) II

- Central Command Regulation (CCR) 415-5 (The Sand Book)

- Army Techniques Publication (ATP) 3-37.10/MCRP 3-17.7N - Base Camps

- Army Doctrine Reference Publication (ADRP) 5-0 (2012) The Operations Process

- Corson and Jasperro (2007) "An All-Hazards Approach to U.S. Military Base Camp Site Selection"

- Krooks et al. (2012) "Contingency Bases and the Problem of Sociocultural Context"

- Army Doctrine Publication (ADP) 5-o (2012)- The Operations Process

- Ducotte (2010) Challenging the Application of PMESII-PT (Political, Military, Economic, Social, Infrastructure, Information, Physical Environment, and Time) in a Complex Environment

- Ezell et al. (2001) "Base Camp Design: Site Selection and Facility Layout"

- ATP 5-19 (2014) - Risk Management

- U.S. Army Corps of Engineers. "Base Camp Development in the Theater of Operations.” Engineer Pamphlet No. 1105-3-1 (19 January 2009) 


\section{Decision Criteria Framework}

\subsection{Design templates}

There are several design choices that must be identified initially that will shape the criteria required for the decision support tool. Decisions at this stage will inform the tool's architecture through selection of relevant criteria and value functions. For example, if ground resupply is necessary, road networks are a required criterion to connect the base camp to its main supplier, but road networks may not be needed as a criterion in some other situations Therefore, making a design choice to consider ground resupply is necessary before including and evaluating the importance of the road transportation criteria. For example, if selected, a design with more roadways connecting the base camp to its main supplier may be preferred to a "one road in, one road out" situation. Proposed design choice factors are shown in Table 1.

Table 1. Design choice factors. Each engagement scenario will have features that relate to different design choices for the base. These features influence how the criteria in the decision framework should be prioritized.

\begin{tabular}{|c|c|c|c|c|c|}
\hline \multirow{2}{*}{ Questions } & Design Choice Factors & 1 & 2 & 3 & 4 \\
\hline & \multicolumn{5}{|l|}{ Mission } \\
\hline 1 & Phase & $0,1,2$ & 3,4 & 5 & \\
\hline 2 & Buildings & Existing & New & Both & \\
\hline 3 & Master planning (expansion) & Yes & No & & \\
\hline 4 & Communication: required lines of sight & Direct & Indirect & Both & NA \\
\hline 5 & Reason for being in host nation & Combat & $\mathrm{HA}$ & Both & NA \\
\hline Emb & \multicolumn{5}{|l|}{ Enemy } \\
\hline 6 & Fire capability & Direct & Indirect & Both & NA \\
\hline 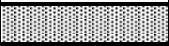 & \multicolumn{5}{|l|}{ Terrain and Weather } \\
\hline 7 & Setting 1 & Urban & Rural & NA & \\
\hline 8 & Setting 2 & Desert & Jungle & NA & \\
\hline 9 & Setting 3 & Temperate & Arctic & NA & \\
\hline 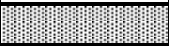 & \multicolumn{5}{|l|}{ Troops and Support Available } \\
\hline 10 & Size & Platoon & Company & Battalion+ & \\
\hline 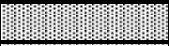 & \multicolumn{5}{|l|}{ Time Available } \\
\hline 11 & Resupply & Ground & Air & Both & NA \\
\hline 12 & $\begin{array}{l}\text { Medical facility on site (golden hour } \\
\text { consideration ) }\end{array}$ & $\begin{array}{l}\text { Surgical } \\
\text { Hospital }\end{array}$ & Aid Station & NA & \\
\hline 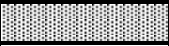 & \multicolumn{5}{|l|}{ Civilian Considerations } \\
\hline 13 & NA & & & & \\
\hline
\end{tabular}

To illustrate this concept, suppose a battlespace commander may site a combat outpost (COP) in a remote location of Afghanistan by selecting the design choice factors circled in Table 2. 
Table 2. Example design choice factors for an Afghan COP.

\begin{tabular}{|c|c|c|c|c|c|}
\hline \multirow{2}{*}{ Questions } & Design Choice Factors & 1 & 2 & 3 & 4 \\
\hline & \multicolumn{5}{|l|}{ Mission } \\
\hline 1 & Phase & $0,1,2$ & 3,4 & 5 & \\
\hline 2 & Buildings & Existing & New & Both & \\
\hline 3 & Master planning (expansion) & Yes & No 2 & & \\
\hline 4 & Communication: required lines of sight & Direct & Indirect & Both & NA \\
\hline \multirow[t]{2}{*}{5} & Reason for being in host nation & Combat & $\mathrm{HA}$ & Both & NA \\
\hline & \multicolumn{5}{|l|}{ Enemy } \\
\hline \multirow[t]{2}{*}{6} & Fire capability & Direct & Indirect & Both & NA \\
\hline & \multicolumn{5}{|l|}{ Terrain and Weather } \\
\hline 7 & Setting 1 & Urban & Rural & NA & \\
\hline 8 & Setting 2 & Desert & Jungle & NA & \\
\hline \multirow[t]{2}{*}{9} & Setting 3 & Temperate & Arctic & NA & \\
\hline & \multicolumn{5}{|l|}{ Troops and Support Available } \\
\hline \multirow[t]{2}{*}{10} & Size & Platoon & Company & Battalion+ & \\
\hline & \multicolumn{5}{|l|}{ Time Available } \\
\hline 11 & Resupply & Ground & Air & Both & NA \\
\hline \multirow[t]{2}{*}{12} & $\begin{array}{l}\text { Medical facility on site (golden hour } \\
\text { consideration) }\end{array}$ & $\begin{array}{l}\text { Surgical } \\
\text { Hos pital }\end{array}$ & Aid Station & NA & \\
\hline & \multicolumn{5}{|l|}{ Civilian Considerations } \\
\hline 13 & NA & & & & \\
\hline
\end{tabular}

The ENSITE tool will map a select group of criteria to different sets of design choices. For example, with a design choice for flat urban desert terrain, the tool would consider and prioritize one subset of criteria; however, with a design choice for mountainous rural arctic terrain, the tool would consider and prioritize a different subset of criteria. The tool will then match criteria to respective data sources (e.g., soil type determined from Food and Agriculture's World Reference base for soil resources and remote sensing data over area of interest [AOI]) and specify appropriate value functions for each criterion as a function of the tactical environment specified by the design choices.

\subsection{Criteria framework and definitions}

The criteria obtained from interviews and background readings were placed into three Army-familiar sets of categories. The criteria are primarily divided into METT-TC categories (Mission, Enemy, Terrain and Weather, Troops and Support Available, Time Available, Civilian Considerations). Terrain and Weather category was then subdivided into OAKOC categories (Observation and Fields of Fire, Avenues of Approach, Key Terrain, Obstacles, Cover and Concealment). The Civilian Considerations category was subdivided into ASCOPE categories (Area, Structures, 
Capabilities, Organizations, People, Events) to analyze the "human terrain." A decision tree showing these three Army-familiar categories in a criteria framework hierarchy is presented in Figure 1.

Figure 1. Army-familiar categories of METT-TC, OAKOC, and ASCOPE are shown as branches and criteria within the decision tree.

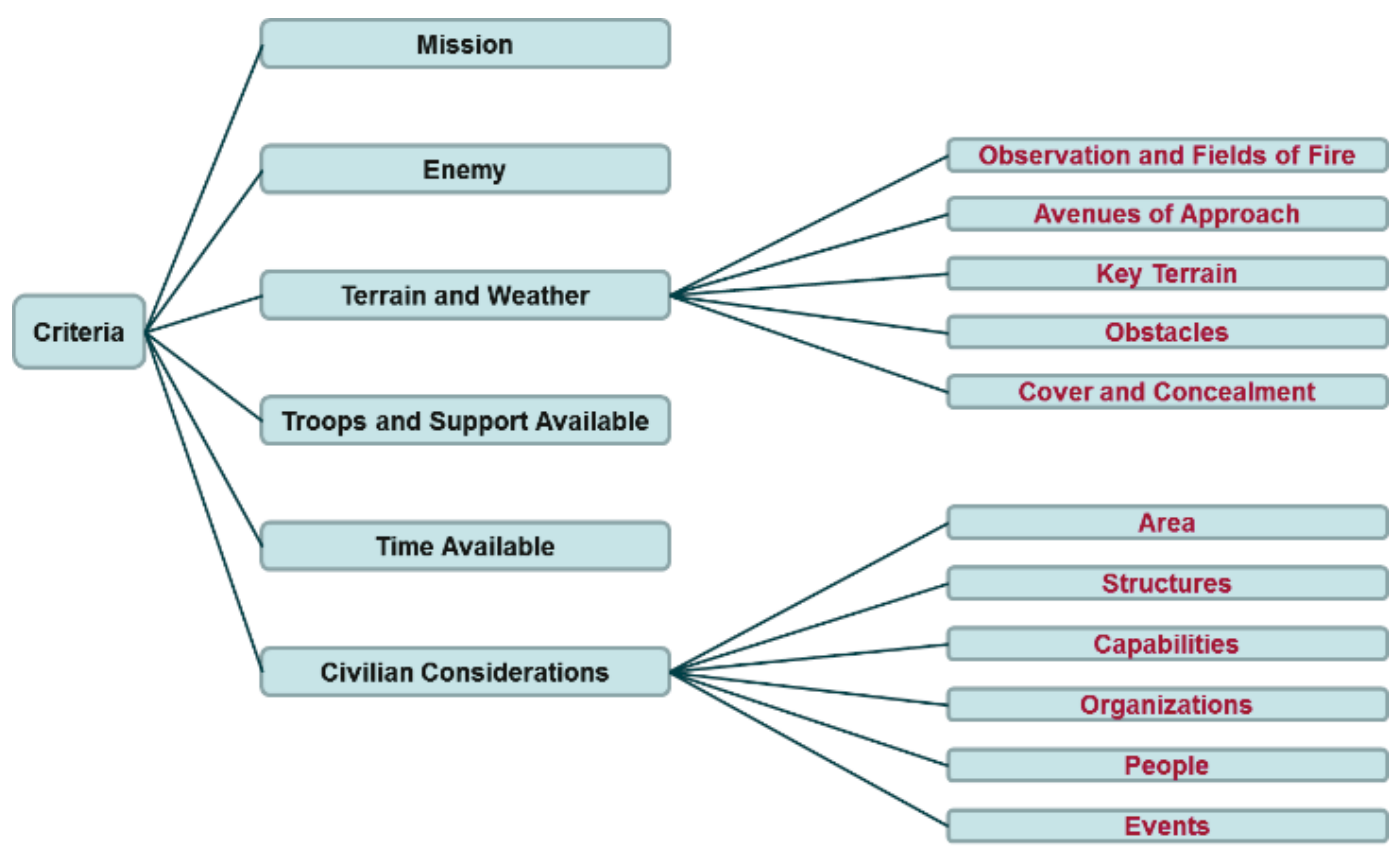

Criteria (i.e., the leaf nodes of the decision tree's branches) include 31 individual characteristics. The tool was envisioned to match each of these criteria to specific data sources (e.g., soil type will be determined from Food and Agriculture's World Reference base* for soil resources and remote sensing data over the AOI).

The subsections that follow provide an outline of specific criteria and their definitions, as gathered from this project's research. The criteria are organized under the decision tree's branches shown in Figure 1.

\subsubsection{Mission}

The purpose of the mission criterion in the first level of the decision tree is to analyze the unit's mission to determine the purpose of base camps and their required functions. This criterion further specified through three

\footnotetext{
* http://www.fao.org/soils-portal/soil-survey/soil-classification/world-reference-base/en/
} 
subcriteria of civilian engagement / counterinsurgency (COIN), reachback, and special facilities, defined below. These subcriteria are highlighted on the expanded portion of the decision tree in Figure 2.

\subsubsection{Civilian engagement/COIN}

Using local material, labor, and construction techniques allows for project success in austere environments (USACE 2015; TRADOC 2009; Gingras 2013; Krooks et al. 2012).

\subsubsection{Reachback}

Obtaining products, services, forces, equipment, or material from organizations that are not forward deployed (USACE 2015; TRADOC 2009)

\subsubsection{Special facilities}

Requirements for specific types of facilities such as airfields, ammunition supply points, and firing ranges will require additional acreage.

Figure 2. Mission criteria highlighted within the decision tree.

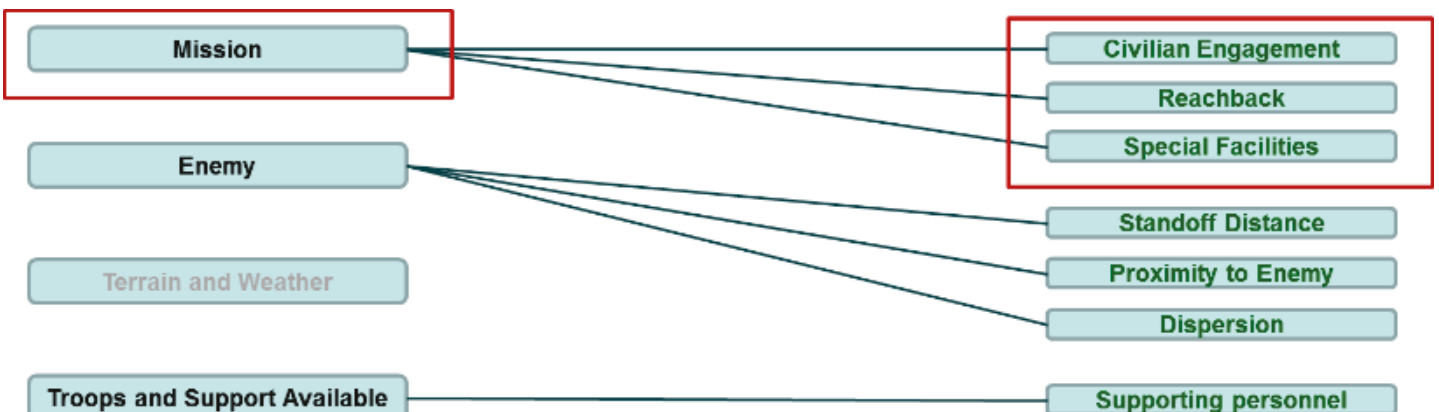

Time Available

\section{Civilian Considerations}

\subsubsection{Enemy}

The purpose of this decision branch is to analyze enemy threats to the base camp and associated protection considerations. The enemy decision branch is highlighted in Figure 3. 


\subsubsection{Standoff distance}

Ideally, maximum standoff should be a primary consideration when personnel are deciding where to locate a site. The goal would be to maximize the distance between the perimeter fence of the base camp and surrounding developed areas or intervisibility lines. The site should provide an unobstructed view and maintain clear zones (Ezell et al. 2001).

\subsubsection{Proximity to enemy populations}

Proximity to enemy populations will influence enemy engagement and the command and control of decisive battlespace terrain (ATP 3-37; ADRP 5-0 2012).

\subsubsection{Dispersion}

Dispersion is the spreading or separation of troops, material, establishments, or activities which are usually concentrated in limited areas to reduce vulnerability. Dispersion criteria may be a function of enemy capabilities and firepower. Increasing dispersion requires a larger site footprint (Ezell et al. 2001).

Figure 3. Enemy criteria highlighted within the decision tree.

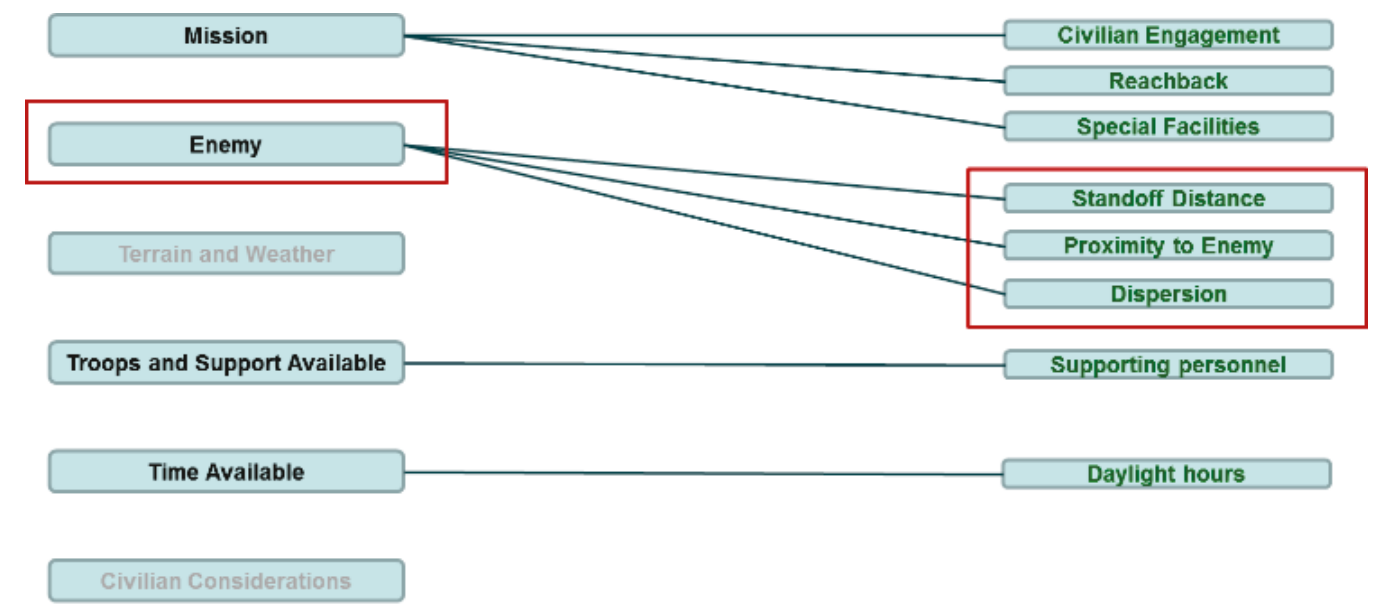

\subsubsection{Terrain and weather}

The purpose of this decision branch is to determine the following: (a) where to place troops to gain the maximum visibility and fire cover, (b) where troops would normally come from when approaching the position, 
(c) what key terrain must be held and what can be given up, (d) what natural or artificial barriers to movement exist, (e) what barriers can be constructed, and (f) what can be used for cover and concealment. These criteria are highlighted on the decision tree in Figure 4, shown at the end of this subsection.

\subsubsection{Intervisibility lines/dead space}

Intervisibility lines are a relative, localized, pattern of limitations on observation, caused by variations in terrain elevation.

\subsubsection{Vantage points}

Locate away from potential enemy vantage points. The following are two examples of potential enemy advantages: (1) higher surrounding terrain or buildings provide direct line of sight for the enemy, and (2) vegetation, drainage channels, ditches, ridges, or culverts can provide enemy concealment. Locate close to potential CB vantage points. For example, high points reduce the effectiveness of an attack and force aggressors to fire up toward the target (Hyperion 2014).

\subsubsection{Roads and highways}

Identify road requirements that could impact security (e.g., how closely located a base is to a public throughway). Be aware of uncontrolled vehicle access, while considering the tradeoff of minimizing access roads compared to a potentially dangerous one-road-in/one-road-out scenario.

\subsubsection{Landing Zone (LZ)}

The ability to provide enduring support via air requires space for a landing zone or airfield. TSLOW considerations mean the following: terrain, slope, landing zone, obstacles, wind.

\subsubsection{Decisive features}

Key locations such as terrain or structures (natural or man-made) that will give a marked advantage to whomever controls it (e.g., a bridge). 


\subsubsection{Landslides}

Natural hazard which can strike instantaneously and result in troop deaths.

\subsubsection{Sandstorms and dust}

Sandstorms may severely limit the lifespan of electronic and computer equipment and inhibit observation of the enemy.

\subsubsection{Hydrology}

Avoid floodplains or other locations that can be inundated by seasonal hydrological changes (e.g., intermittent rivers or flash floods).

\subsubsection{Soil}

Certain soil types are more advantageous for construction, trafficability, and waste management options.

\subsubsection{Aquifer access}

Suitability of wells depends on the depth required to reach the water.

\subsubsection{CBRN hazards}

Soldiers may be exposed to a range of CBRN hazards that carry potential health risks (Corson and Jaspero 2007; ATP 5-19).

\subsubsection{Natural and existing barriers}

Features used for protective measures (e.g., mountains, rivers, bays, cliffs). Also, the use of trees, fences, land forms, or buildings can obscure sight paths and impede an enemy attack, providing defense of depth.

\subsubsection{Vegetation (relating to Obstacles)}

Vegetation may provide an ideal deterrent or natural barrier (e.g., swamps, thick forests) (Hyperion 2014). 


\subsubsection{Vegetation (relating to Cover and Concealment)}

Certain vegetation may provide protection from the effects of weapons fire (e.g., direct, indirect, and air-to-ground) or concealment from observation (e.g., thick forest canopy).

\subsubsection{Elevation and slope}

High ground may be used for strategic advantage. Low-lying areas can facilitate the effects from a possible biological or chemical attack. In addition, the slope of terrain largely determines the feasibility of aircraft landing zones (USACE 2015; Hyperion 2014).

Figure 4. Terrain and weather criteria (in green at right) are highlighted within the decision model. Note that they are subdivided from the OAKOC objectives.

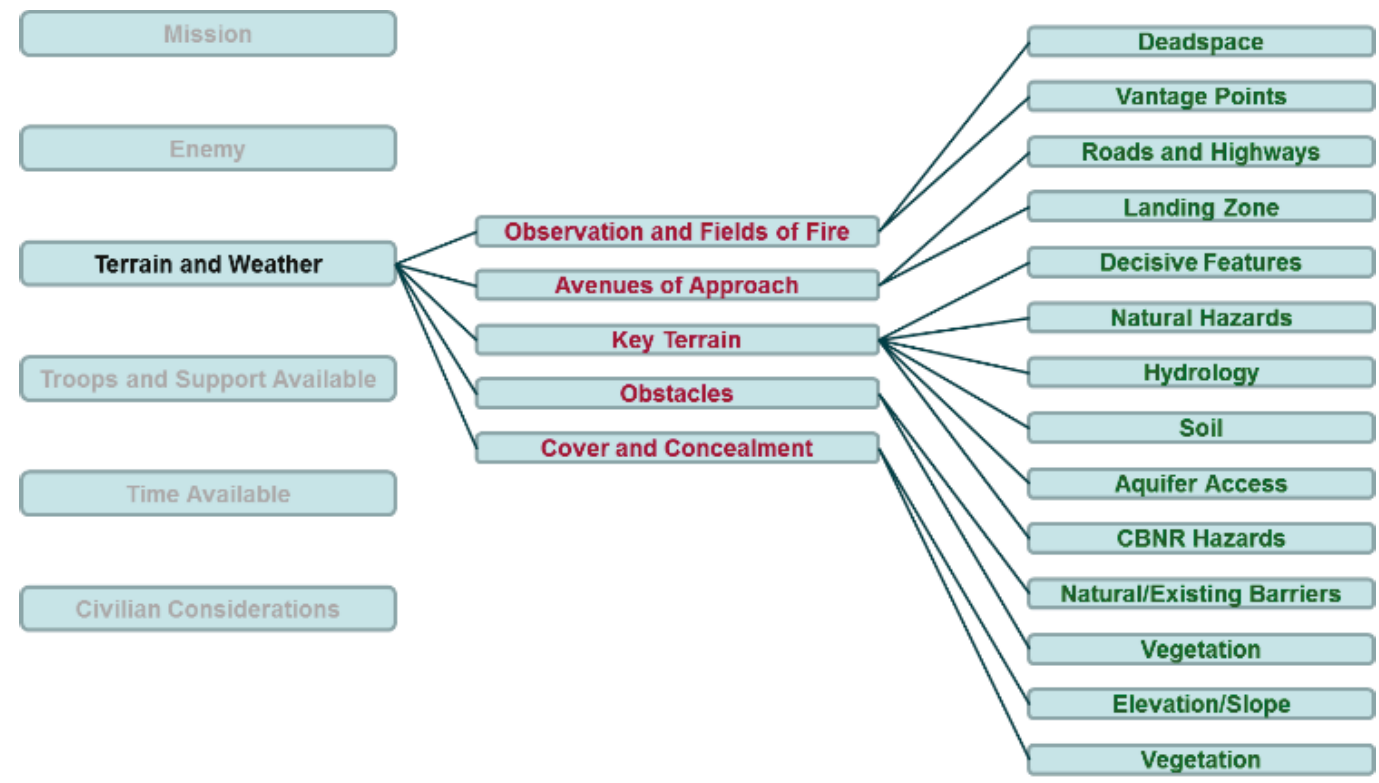

\subsubsection{Troops and support available}

The purpose of this decision branch is to determine the availability of workers to perform base camp construction and operational tasks. These criteria are highlighted on the decision tree in Figure 5.

\subsubsection{Supporting personnel}

Other base camps or host nation (HN) forces (e.g., Afghan National Army) can provide support in an attack. Local workers, equipment, and services can perform base camp construction and operation tasks. 
Figure 5. Troops and support available criterion is highlighted by red outline.

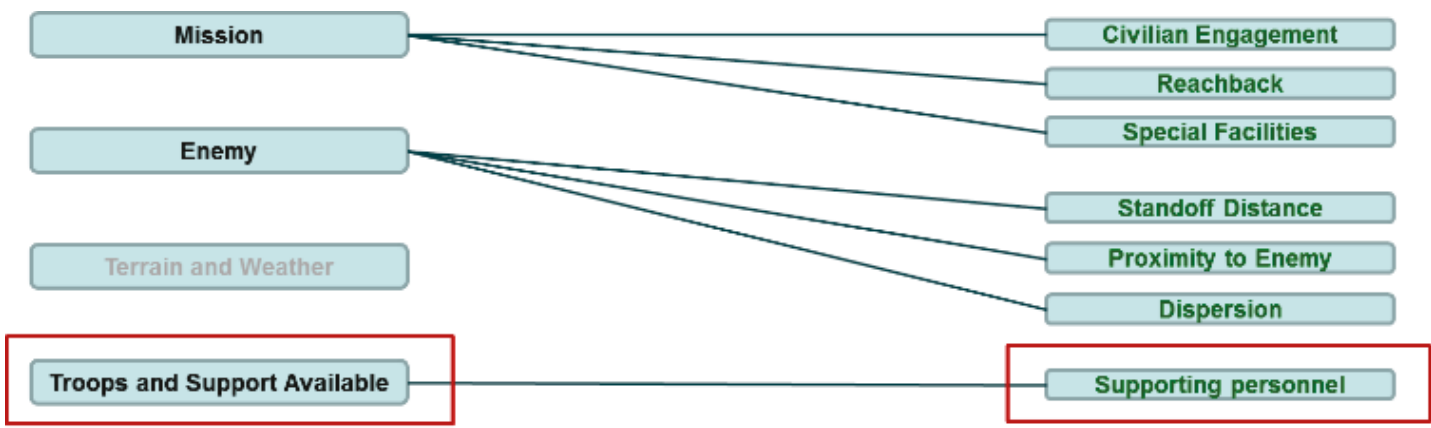

Time Available

\section{Civilian Considerations}

\subsubsection{Time available}

The purpose of this decision branch is to analyze the time available for base camp construction and operational tasks. These criteria are highlighted on the decision tree in Figure 6.

\subsubsection{Daylight hours}

Surrounding terrain can limit daylight hours, which in turn will affect solar recharge, time available for construction, and other diurnal operations. For example, daylight hours can affect the capacity for solar-powered laptop computers and secure wireless networks that allow critical communications directly from the field to reachback experts. The duration of sunlight exposure can also dictate the need for blacking out a base camp.

Figure 6. Time-available criteria are highlighted by red outline.

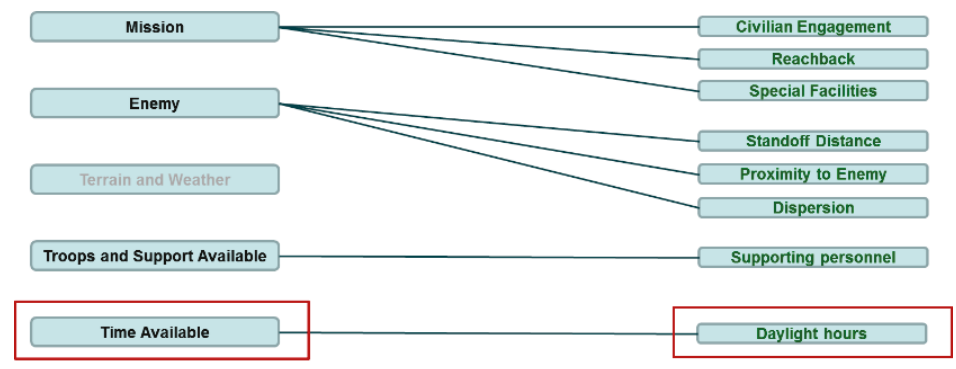

\subsubsection{Civilian considerations}

The purpose of this decision branch is to analyze the ASCOPE considerations in the AOI. These considerations include (1) where people live, work, 
play, meet, and worship; (2) how a structure's location, function, and capabilities support or hinder operations; (3) who in the community is capable of providing key functions and services; (4) what are the different nonmilitary groups or institutions; (5) who are the nonmilitary personnel that military forces will encounter in the area of operations (AO), and how do they interact; and (6) what events will significantly affect organizations, people, or military operations, and when will they occur. These criteria are explained in the subsections below and highlighted on the decision tree in Figure 7 at the end of this subsection.

\subsubsection{Construction materials}

Sources of natural construction resources (e.g., water, gravel, and fill materials).

\subsubsection{Boundaries}

Political, ethnic, or tribal boundaries and locations of government centers.

\subsubsection{Religious and historical sites}

Respecting sacred sites helps build rapport with the host nation.

\subsubsection{Local infrastructure}

Availability of existing structures and local facilities and infrastructure that can help sustain base camps, as outlined below:

- Traditional high-payoff targets such as bridges, communication towers, power plants, and dams.

- International and locally significant sites that include the following: churches, mosques, national libraries, hospitals, cemeteries, historical ruins, religious sites, cultural areas, and other protected sites.

- Practical sites that may influence operations such as jails, warehouses, toxic industrial storage sites, print plants, and television and radio stations.

\subsubsection{Local economy}

Ability of local economies and local businesses and laborers to support base camps, with services as listed and annotated below. 
- Sewer: local government (mayor and council)

- Water: tribal leaders (historical - for hundreds of years, tribal leader controlled and protected wells.

- Electricity: town engineer

- Academic: government and religious leaders

- Trash: private business (local entrepreneurs)

- Medical: tribal doctors

- Security: local police, tribal militia

\subsubsection{Local groups}

Organizations within and outside the AOI that can support or affect base camps, including local labor unions, criminal organizations, community watch groups, and governmental or nongovernmental agencies and organizations.

\subsubsection{Land ownership}

In many places, property ownership standards differ from U.S. standards, causing execution problems with land titles, including the risk of duplicate or erroneous payments.

\subsubsection{Dislocated civilians}

Effects of indigenous and transient civilians on base camps.

\subsubsection{Local activities}

Routine, cyclical, planned, or spontaneous activities that can affect base camps (e.g., holidays, elections, celebrations, demonstrations). 
Figure 7. Civilian considerations criteria are highlighted in green and connected to ASCOPE considerations shown in red.

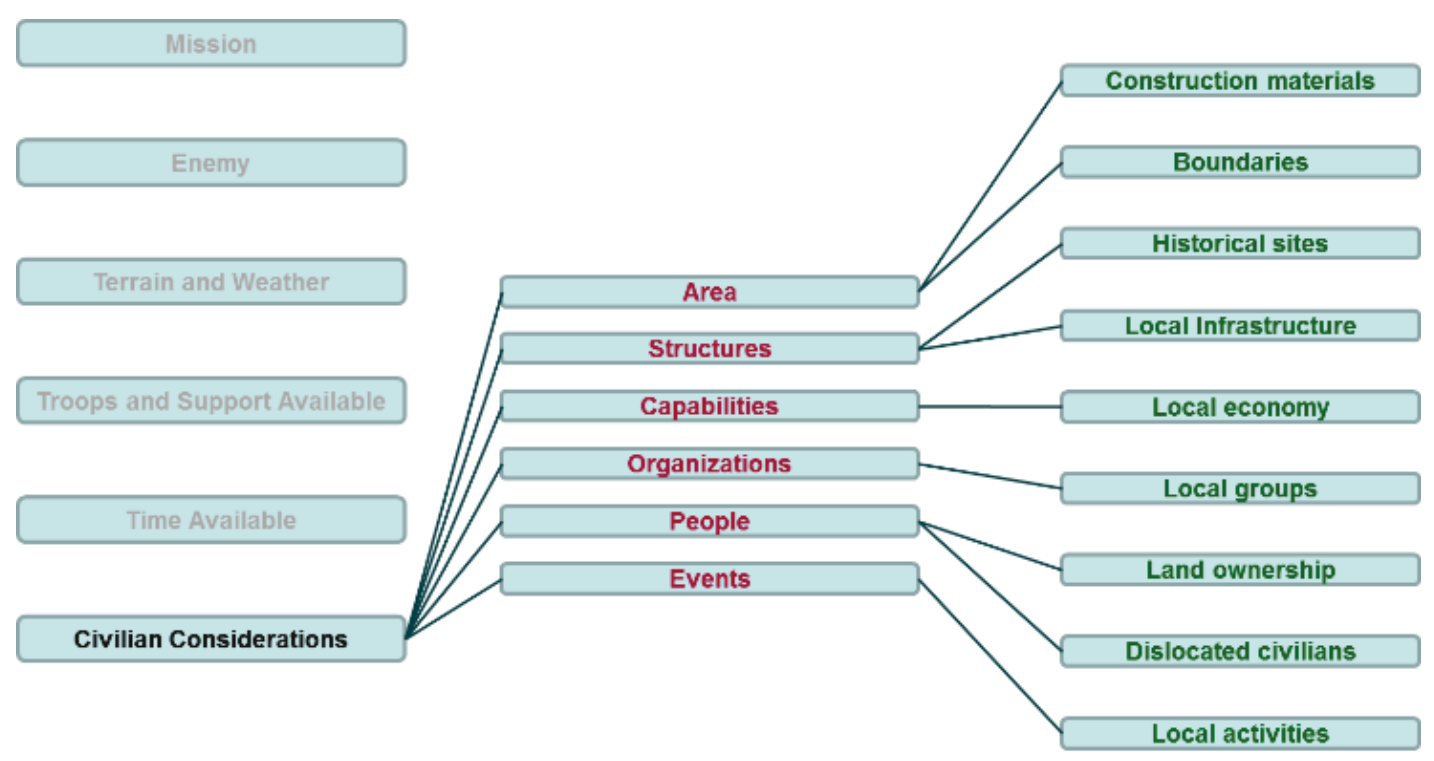




\subsection{ENSITE scoring of criteria for site suitability}

When run, the ENSITE tool scores regions for base camp siting suitability. A mock-up of this interface depicting the scores of different gridded regions is shown in Figure 8. Scoring is displayed on a red/yellow/green scale, with red being the least suitable and green being the most suitable site for a base camp.

Figure 8. Preliminary site analysis, with red as least suitable site and green as most suitable site.

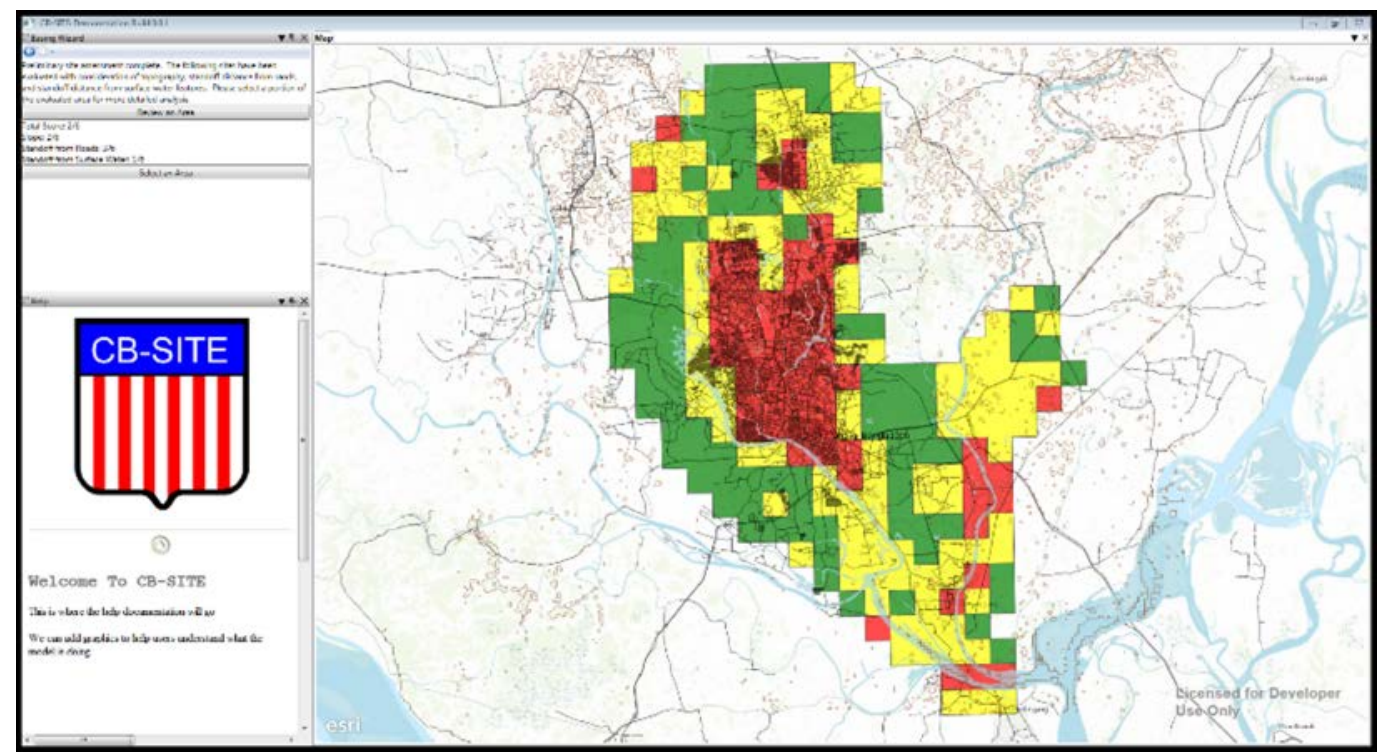




\section{Discussion}

Significant effort in FY16-FY17 was made to explore reasonable analytical framings for the site suitability analysis, including identification of appropriate methods, criteria, and parameters for evaluating different spatial areas for suitability as new CBs. The RADS team worked with ENSITE colleagues focused on tool development to transition this knowledge and its context and rationale so that it can influence how these models and assessments are being developed.

The RADS team explored the types of criteria and design choices that can influence $\mathrm{CB}$ siting in general, but it did not explore the ranges or specific values those criteria could and should take in different military mission phases. The team engaged with subject matter experts to begin to answer these more specific questions and to refine the decision analytic framework. The team refined the most important subset of ten criteria and determined the appropriate weighting schemes for a generalized combat mission.

Furthermore, the RADS team and other ENSITE team member efforts to date have focused primarily on developing frameworks and models to support CB-siting decisions. These products have not yet been demonstrated in a fully detailed and realistic example. Future efforts may include developing a hypothetical but realistic case scenario that can be used to demonstrate relevant aspects of the ENSITE framework and tools. 


\section{References}

ADRP 5-o. May 2012. The Operations Process. Washington, DC. Headquarters, Department of the Army.

ATP 3-37.10/MCRP 3-40D.13. January 2017. Base Camp Overview. Washington, DC: Headquarters, Department of the Army.

ATP 5-19. April 2014. Risk Management. Washington, DC: Headquarters, Department of the Army.

Bailey, Michael, LTC Robert Dixon, COL Marc Harris, CSM Daniel Hendrex, MAJ Nicholas Melin, SGM Richard Russo (Strategic Studies Group Fellows with Chief of Staff of the Army). 2013. "A Proposed Framework for Appreciating Megacities: A U.S. Army Perspective.” Small Wars Journal: 21 April.

Corson, Mark, and Christopher Jasperro. 2007. "An All-Hazards Approach to U.S. Military Base Camp Site Selection.” The Geographical Bulletin 48(2): 75-84.

Ducotte, MAJ Brian M. 2010. Challenging the Application of PMESII-PT in a Complex Environment. AY 2010-1, SAMS monograph. Fort Leavenworth, KS: School of Advanced Military Studies (SAMS), U.S. Army Command and General Staff College.

Ezell, Barry C., and Mark J. Davis. August 2001. "Base Camp Design: Site Selection and Facility Layout.” West Point, NY: United States Military Academy, Operations Research Center.

Gingras, Robert. 2013. The Challenge of Modern Contingency Base Management during Sustained Land Operations. Technical report for Army War College fellowship. Carlisle, PA: U.S. Army War College.

Hyperion Technical Group, Inc. 2014. "Volume 2: Technical Proposal.” FY2014 Rapid Innovation Fund BAA HQo034-14-BAA-RIF-0001 ARMY-COE1-953. Tupelo, MS: Hyperion Technology Group, Inc.

Krooks, David A., Lucy A. Whalley, and H. Garth Anderson. 2012. "Contingency Bases and the Problem of Sociocultural Context." ERDC/CERL TN-12-2. Champaign, IL: Engineer Research and Development Center-Construction Engineering Research Laboratory (ERDC-CERL).

TRADOC (U.S. Army Training and Doctrine Command). 2009. “The U.S. Army Concept Capability Plan for Army Base Camps in Full Spectrum Operation for the Future Modular Force 2015-2024." Pamphlet 525-7-7. Fort Eustis, VA: U.S. Army TRADOC.

USACE. October 2015. USACE Overseas Contingency Operations Playbook; Special Study: Lessons and Best Practices. No 16-01. Winchester VA: USACE Transatlantic Division and the Center for Army Lessons Learned. Available at: http://usacac.army.mil/sites/default/files/publications/16-01.pdf. 


\section{Appendix A: Past Examples}

The Army's interest in developing a holistic framework for evaluating potential base camp locations for suitability is motivated, in part, by past failures where relevant factors were initially overlooked, leading to significant risk, damage, or loss. Several examples of these past failures in facility siting are summarized below.

\section{COP Keating and OP Fritsch (Afghanistan)}

The joint base camp for Combat Outpost (COP) Keating and Observation Post (OP) Fritsch are infamously remembered for the deadly attack on 3 October 2009, when 300 Taliban simultaneously assaulted these two locations. Prior to the attack, the base camp already had suffered from siting vulnerabilities. The approach to the base camp had been nicknamed "Heart Attack Ridge" by pilots due to its steep slope and hazardous obstacles that made air resupply very difficult. Additionally, COP Keating was surrounded by unsecured high ground on all sides. Months prior to the attack, soldiers lost support from the local population. During the attack, which became known as the Battle of Kamdesh, eight U.S. soldiers were killed, and the base camps were immediately abandoned.

NOTE: Inadequate consideration of specific criteria that may have played a role in the base camp's vulnerabilities include roadways, civilian engagement, vantage points, topography, obstacles, and landing zones.

\section{FOB Fenty (Afghanistan)}

Forward Operating Base (FOB) Fenty is a base built around Jalalabad Airport. On 2 December 2012, a heavily armed Taliban assault team attacked the main entrance. The attack began with three vehicle-borne improvised explosive device (VBIED) detonations near the entrance of the base in an effort to breach the perimeter. After more than two hours of fighting, the Taliban were beaten back by Afghan and Coalition forces, backed by attack helicopters. The main gate where that attack took place abuts Highway A01, also known as Kabul-Jalalabad-Torkham Highway.

NOTE: Inadequate consideration of specific siting criteria that may have played a role in this attack include nearby roads and highways. 


\section{COP Zerok (Afghanistan)}

COP Zerok was attacked on the Fourth of July, 2009. From the unsecured high ground surrounding the COP, insurgents opened fire on all sides in a complex attack. Later, a VBIED penetrated the perimeter, and the COP commander was forced to call Alamo, redirecting all aircraft in Afghanistan to their location to prevent COP Zerok from being overrun.

NOTE: Inadequate consideration of specific siting criteria that may have played a role in this attack include nearby roadways and vantage points.

\section{COP Kahler and OP Topside (Afghanistan)}

COP Kahler and OP Topside were attacked on 18 July 2008 during what became known as the Battle of Wanat. OP Topside was established on the ridge to the east of COP Kahler; however, the chosen terrain was not ideal due to significant drawbacks that included dead spaces in an adjacent ravine and in a nearby civilian compound. The COP was adjacent to the local village, where elders were cooperating and planning an attack with local insurgents. Prior to the attack, troops did not finish establishing a defensive perimeter at OP Topside due to heat, excessively hard soil, and equipment failure. During the attack, the local mosque, bazaar, and hotel were all used as insurgent firing positions. The attack left nine U.S. soldiers killed in action and 27 wounded. In the aftermath of the attack, it was clear that the town had been completely infiltrated by insurgents and used as a base for the attack. U.S. forces withdrew from the area shortly after the attack.

NOTE: Inadequate consideration of specific siting criteria that may have played a role in this attack include intervisibility lines, ${ }^{*}$ dead space $^{\dagger}$, civilian engagement, vantage points, soil, and topography.

\section{COP Ranch House (Afghanistan)}

COP Ranch House was located on a 7,000 ft high mountainside. The COP's helicopter landing zone was centered on the roof of a large one-

\footnotetext{
* Intervisibility lines are the relatively localized pattern of limitations on observations, caused by (often subtle) variations in terrain elevation.

† Dead space refers to locations around a base camp that cannot be observed from line-of-sight within the base camp itself.
} 
story wooden building. In August 2007, a downhill attack from a higher elevation by 60 insurgents exploited the COP's two known vulnerabilities: isolation from the closest city of Aranus, Afghanistan, and dependence on helicopter transport. As a result, the COP was abandoned less than two months after the attack.

NOTE: Inadequate consideration of specific siting criteria that may have played a role in this attack include roadways and civilian engagement.

\section{Camp Alpha (Iraq)}

Camp Alpha was positioned on top of the historical site of Babylon, Its location resulted in major damages to the archeological site of the Hanging Gardens of Babylon, specifically the Ishtar Gate and other historical antiquities, and this damage resulted in international outrage.

NOTE: Inadequate consideration of specific siting criteria that may have played a role in this failure include a general awareness of religious and historical sites.

\section{Camp Casey and Camp Hovey (South Korea)}

Camp Casey and Camp Hovey are two U.S. military bases that were significantly damaged and had to be temporarily shut down as a result of massive downpours and landslides in July 2011.

NOTE: Inadequate consideration of specific siting criteria that may have played a role in this failure include floodplains and areas prone to landslides.

\section{Camp Montheith (Kosovo)}

Camp Montheith was established in 1999. Two years later, the U.S. Army Chemical Corps noticed a large battery factory was located $300 \mathrm{~m}$ from the base. Reconnaissance discovered large amounts of industrial waste being dumped behind the plant. The hazardous heavy metals were contaminating the camp's air, soil, and groundwater supply. In addition to being an environmental hazard, the toxic barrels produced a direct threat via the possibility that a single enemy agent, armed with a fuel truck and a small incendiary bomb, could park near the toxic area and set the truck ablaze, 
forcing evacuation of the camp. Also, $10 \mathrm{~km}$ from the camp lay a large reservoir behind a concrete dam. If the dam were destroyed, the released water could potentially inundate the camp.

NOTE: Inadequate consideration of specific siting criteria that may have played a role in this failure include nearby presence of chemical, biological, radiological, and nuclear (CBRN) hazards and location within floodplains.

\section{Karshi-Khanabad Air Base (Uzbekistan)}

Routine environmental inspection at Karshi-Khanabad Air Base, a military base that over 5,000 U.S. troops had passed through, turned up traces of nerve and mustard gases from prior activity.

NOTE: Inadequate consideration of specific siting criteria that may have played a role in this failure include $\mathrm{CBRN}$ hazards. 


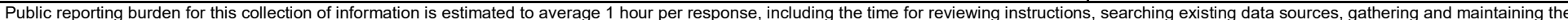

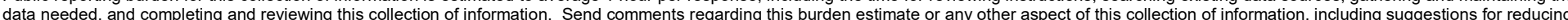

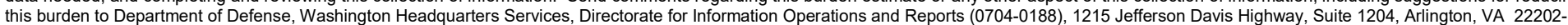

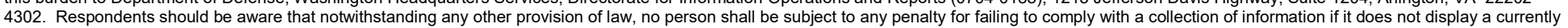
valid OMB control number. PLEASE DO NOT RETURN YOUR FORM TO THE ABOVE ADDRESS.
1. REPORT DATE (DD-MM-YYYY)
December 2017
Final

4. TITLE AND SUBTITLE

Identifying Key Factors Relevant for Base Camp Siting

5a. CONTRACT NUMBER

5b. GRANT NUMBER

$\mathrm{T} 45$

5d. PROJECT NUMBER

455009

5e. TASK NUMBER

5f. WORK UNIT NUMBER

7. PERFORMING ORGANIZATION NAME(S) AND ADDRESS(ES)

U.S. Army Engineer Research and Development

Center (ERDC)

Construction Engineering Research Laboratory

(CERL)

PO Box 9005

Champaign, IL 61826-9005

9. SPONSORING / MONITORING AGENCY NAME(S) AND ADDRESS(ES)

Assistant Secretary of the Army for Acquisition,

Logistics, and Technology

103 Army Pentagon

Washington, DC 20314-1000

U.S. Army Engineer Research and

Development Center (ERDC)

Environmental Laboratory (EL)

3909 Halls Ferry Road

Vicksburg, MS 39180-6199

\section{DISTRIBUTION / AVAILABILITY STATEMENT}

Approved for public release. Distribution is unlimited.

\section{SUPPLEMENTARY NOTES}

\section{ABSTRACT}

To sustain itself as the world's premier land power, the U.S. Army needs the capability to support expeditionary forces by projecting a minimal basing footprint with reduced logistical burdens. Strategically sited contingency bases (CBs) allow the Army's expeditionary forces to rapidly respond throughout a joint area of operations. To assist with this goal, the Army is funding work in the Engineer Site Identification for the Tactical Environment (ENSITE) program, which is dedicated to empowering military planners with the data and knowledge to site CB locations. The work reported here explores reasonable analytical framings for the site suitability analysis, including identification of appropriate methods, criteria, and parameters for evaluating different spatial areas for suitability as new CBs. This work utilizes the specialized capabilities and knowledge of the U.S. Army Engineer, Research, and Development Center's Risk and Decision Science team (RADS), who worked with ENSITE colleagues and subject matter experts to identify key factors relevant for locating CBs.

\section{SUBJECT TERMS}

Military bases_-Location, Data curation, Geospatial data, Computer programs, Military planning, Contingency base, ENSITE

\begin{tabular}{|c|c|c|}
\hline \multicolumn{3}{|c|}{ 16. SECURITY CLASSIFICATION OF: } \\
\hline $\begin{array}{l}\text { a. REPORT } \\
\text { Unclassified }\end{array}$ & $\begin{array}{l}\text { b. ABSTRACT } \\
\text { Unclassified }\end{array}$ & $\begin{array}{l}\text { c. THIS PAGE } \\
\text { Unclassified }\end{array}$ \\
\hline
\end{tabular}

\begin{tabular}{|c|c|c|}
$\begin{array}{l}\text { 17. LIMITATION } \\
\text { OF ABSTRACT }\end{array}$ & $\begin{array}{c}\text { 18. NUMBER } \\
\text { OF PAGES }\end{array}$ & 19 \\
\cline { 3 - 3 } & 35 & \\
\end{tabular}
3. DATES COVERED (From - To)
5c. PROGRAM ELEMENT NUMBER
10. SPONSOR/MONITOR'S ACRONYM(S)
1. SPONSOR/MONITOR'S REPORT

\section{NUMBER \\ 8. PERFORMING ORGANIZATION REPORT} ASA(ALT) NUMBER(S)

ERDC TR-17-17 